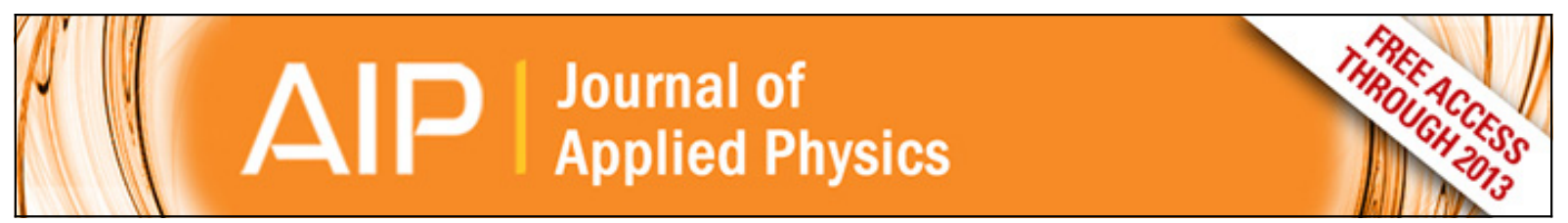

\title{
Al2O3/TiO2 stack layers for effective surface passivation of crystalline silicon
}

Dongchul Suh, Duk-Yong Choi, and Klaus J. Weber

Citation: Journal of Applied Physics 114, 154107 (2013); doi: 10.1063/1.4825258

View online: http://dx.doi.org/10.1063/1.4825258

View Table of Contents: http://scitation.aip.org/content/aip/journal/jap/114/15?ver=pdfcov

Published by the AIP Publishing

$\stackrel{A}{A} \mathbb{P} P$ Re-register for Table of Content Alerts

Create a profile.

Sign up today! 


\title{
$\mathrm{Al}_{2} \mathrm{O}_{3} / \mathrm{TiO}_{2}$ stack layers for effective surface passivation of crystalline silicon
}

\author{
Dongchul Suh, ${ }^{1, a)}$ Duk-Yong Choi, ${ }^{2}$ and Klaus J. Weber ${ }^{1}$ \\ ${ }^{1}$ Center for Sustainable Energy Systems, College of Engineering and Computer Science, \\ The Australian National University, Canberra, Australian Capital Territory 0200, Australia \\ ${ }^{2}$ Laser Physics Centre, Research School of Physics and Engineering, The Australian National University, \\ Canberra, Australian Capital Territory 0200, Australia
}

(Received 26 July 2013; accepted 30 September 2013; published online 16 October 2013)

\begin{abstract}
For silicon surface passivation, we investigate stack layers consisting of a thin $\mathrm{Al}_{2} \mathrm{O}_{3}$ layer and a $\mathrm{TiO}_{2}$ capping layer deposited by means of thermal atomic layer deposition (ALD). In this work, we studied the influence of different thermal post-deposition treatments and film thickness for the activation of passivating $\mathrm{ALD} \mathrm{Al}_{2} \mathrm{O}_{3}$ single layers and $\mathrm{Al}_{2} \mathrm{O}_{3} / \mathrm{TiO}_{2}$ stack layers. Our experiments show a substantial improvement of the passivation for the $\mathrm{Al}_{2} \mathrm{O}_{3} / \mathrm{TiO}_{2}$ stack layers compared to a thin single $\mathrm{Al}_{2} \mathrm{O}_{3}$ layer. For the stacks, especially with less than $10 \mathrm{~nm} \mathrm{Al}_{2} \mathrm{O}_{3}$, a $\mathrm{TiO}_{2}$ capping layer results in a remarkably lower surface recombination. Effective fixed charge density of $\mathrm{Al}_{2} \mathrm{O}_{3} / \mathrm{TiO}_{2}$ stack layers increases after $\mathrm{TiO}_{2}$ deposition and $\mathrm{O}_{2}$ annealing. It is also demonstrated that the enhanced surface passivation can be mainly related to a remarkably low interface defect density of $1.1 \times 10^{10} \mathrm{eV}^{-1} \mathrm{~cm}^{-2}$, whereas post- $\mathrm{TiO}_{2}$ heat treatment in $\mathrm{O}_{2}$ ambience is not beneficial for the passivation of silicon, which is attributed to increasing interface defect density of stack layers. (C) 2013 AIP Publishing LLC. [http://dx.doi.org/10.1063/1.4825258]
\end{abstract}

\section{INTRODUCTION}

Charge carrier recombination in the silicon is one of the most significant loss mechanisms in conventional solar cells, and recombination losses must be decreased in order to obtain higher efficiency solar cells. ${ }^{1}$ Surface recombination losses are reduced by passivating the surfaces using dielectric films. Surface passivation is becoming more important as the wafer thickness is continuously being decreased in order to reduce material costs. Traditionally, thermally grown $\mathrm{SiO}_{2}$ has been used as effective passivation layer in high-efficiency solar cells., ${ }^{2,3}$ For low-temperature passivation of heterojunction solar cells, hydrogenated amorphous silicon deposited by plasma-enhanced chemical vapor deposition (PECVD) was introduced. ${ }^{4}$ Amorphous hydrogenated silicon nitride, a-SiN $\mathrm{x}_{\mathrm{x}}: \mathrm{H}$, is in common use for passivating the front $\mathrm{n}^{+}$emitter of $\mathrm{p}$-type silicon solar cells. ${ }^{5,6}$ There are two advantageous effects of $\mathrm{a}-\mathrm{SiN}_{\mathrm{x}}: \mathrm{H}$ on passivation. Chemical passivation due to interfacial bonding occurs between the a-SiN $\mathrm{N}_{\mathrm{x}}: \mathrm{H}$ layer and the silicon substrate, while field-effect passivation is caused by fixed positive charge near the silicon surface. ${ }^{7}$ Also a-SiN $\mathrm{x}$ :H layers often play the important role of the anti-reflection coating, in addition to providing good surface passivation.

However, in order to reduce surface recombination losses further for $\mathrm{p}^{+}$emitters of n-type silicon cells, a negatively charged dielectric is desirable, as the positive charge in $\mathrm{a}-\mathrm{SiN}_{\mathrm{x}}: \mathrm{H}$ films results in a lowering of the majority carrier density at the surface and an increase in recombination. Further, for passivated emitter and rear cell (PERC) type solar cells on p-type silicon, parasitic shunting can occur when dielectrics with a fixed positive charge are used, due to the formation of an inversion layer. ${ }^{8}$ Aluminum oxide $\left(\mathrm{Al}_{2} \mathrm{O}_{3}\right)$

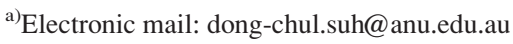

has been shown to exhibit a high density of negative charge and provide a good level of surface passivation on both p- and n-type silicon. ${ }^{9-11}$ Moreover, $\mathrm{Al}_{2} \mathrm{O}_{3}$ also provides excellent surface passivation on heavily doped $\mathrm{p}^{+}$emitters. ${ }^{12,13}$ The passivation properties of $\mathrm{Al}_{2} \mathrm{O}_{3}$ are associated with the combination of a low interface defect density and an enhanced field-effect passivation. ${ }^{14}$

$\mathrm{Al}_{2} \mathrm{O}_{3}$ films have been demonstrated to provide excellent surface passivation; however, they cannot be used by themselves as effective anti-reflection coatings due to the low refractive index $(\sim 1.6)$. Hence, for use on the front side of solar cells, dielectric stacks consisting of a thin layer of $\mathrm{Al}_{2} \mathrm{O}_{3}$ and a thicker layer of a dielectric with suitable refractive index are the best solution. Recently, some results of $\mathrm{Al}_{2} \mathrm{O}_{3} / \mathrm{a}-\mathrm{SiN}_{\mathrm{x}}: \mathrm{H}$ stacks have been reported for anti-reflection as well as surface passivation purposes. ${ }^{13,15}$ In the stacked $\mathrm{Al}_{2} \mathrm{O}_{3} / \mathrm{a}-\mathrm{SiN}_{\mathrm{x}}: \mathrm{H}$ layers, stacks optimized for low surface reflection resulted in an improvement in the final photovoltaic characteristic of the solar cells. Compared to single $\mathrm{Al}_{2} \mathrm{O}_{3}$ layers, $\mathrm{Al}_{2} \mathrm{O}_{3} / \mathrm{PECVD}$ a-SiN $\mathrm{X}_{\mathrm{x}}: \mathrm{H}$ stacks also showed a further reduction in the surface recombination velocity, which was attributed to the hydrogenation of $\mathrm{Si} / \mathrm{Al}_{2} \mathrm{O}_{3}$ interface states, leading to a reduction in the interface state density. ${ }^{16}$ However, the extinction coefficient, especially below $600 \mathrm{~nm}$, for $\mathrm{a}-\mathrm{SiN}_{\mathrm{x}}: \mathrm{H}$ films increases greatly as the $\mathrm{Si}: \mathrm{N}$ ratio is increased, which is undesirable for the application as an antireflection coating. In contrast, $\mathrm{TiO}_{2}$ has a relatively high refractive index and moderate extinction coefficients for wavelengths down to $400 \mathrm{~nm} .{ }^{17} \mathrm{TiO}_{2}$ is therefore also a good candidate as the top layer of $\mathrm{Al}_{2} \mathrm{O}_{3}$ /dielectric stack due to its excellent optical properties. Another advantage of the use of $\mathrm{TiO}_{2}$ is that the entire $\mathrm{Al}_{2} \mathrm{O}_{3} / \mathrm{TiO}_{2}$ stack can be deposited by atomic layer deposition (ALD) in the same chamber with excellent layer thickness control and efficient use of chemical precursors. Further, the use of ALD allows the creation 
of materials with graded refractive index. Using $\mathrm{Al}_{2} \mathrm{O}_{3}$ and $\mathrm{TiO}_{2}$, it would be possible to grade the refractive index between the extremes given by the refractive indices of the two materials, ${ }^{18}$ allowing further reductions in optical reflectance.

Recently, improved surface passivation has been reported when $\mathrm{Al}_{2} \mathrm{O}_{3}$ is combined with $\mathrm{TiO}_{2}$ in a type of alternating layer ${ }^{19}$ and bilayer, ${ }^{20}$ compared to passivation obtained by $\mathrm{Al}_{2} \mathrm{O}_{3}$ only. However, the origin of this enhanced passivation is still under investigation. In this paper, we investigate the surface passivation of $\mathrm{Al}_{2} \mathrm{O}_{3} / \mathrm{TiO}_{2}$ stacks. Of particular interest are stacks where the $\mathrm{Al}_{2} \mathrm{O}_{3}$ layer is sufficiently thin (generally in the order of $10 \mathrm{~nm}$ or less) that it has minimal impact on the optical properties of the stack. The focus is on investigating the underlying mechanisms of c-Si surface passivation as obtained by $\mathrm{Al}_{2} \mathrm{O}_{3} / \mathrm{TiO}_{2}$ stacks.

\section{EXPERIMENTAL DETAILS}

Symmetrical $\mathrm{p}^{+} / \mathrm{n} / \mathrm{p}^{+}$structures on (100) damage-etched n-type float-zoned $\mathrm{Si}$ wafers were used for the measurement of the emitter saturation current density $\mathrm{J}_{0 \mathrm{e}}$. The wafers had a resistivity of $100 \Omega \mathrm{cm}$ and a thickness $500 \mu \mathrm{m}$. They were exposed to $\mathrm{BBr}_{3}$ at a temperature of $910^{\circ} \mathrm{C}$ in a diffusion furnace. The sheet resistance of the $\mathrm{p}^{+}$diffusion was $100 \Omega / \square$. Un-diffused and polished p-type Czochralski Si wafers with a resistivity of $1-10 \Omega \mathrm{cm}$ were used for capacitance-voltage and Kelvin probe measurements. Before deposition, the samples were treated with a conventional RCA clean followed by a dip in diluted HF. Deposition of thin $\mathrm{Al}_{2} \mathrm{O}_{3}$ and $\mathrm{TiO}_{2}$ layers was carried out in a commercial hot-wall flow-type ALD reactor (TFS200, Beneq). Trimethylaluminum and titanium chloride were used as aluminum and titanium precursors, respectively. $\mathrm{H}_{2} \mathrm{O}$ were used as the oxidant for both $\mathrm{TiO}_{2}$ and $\mathrm{Al}_{2} \mathrm{O}_{3}$ films in order to keep the process simple by using the same standard oxidant. The films were prepared by alternating metal precursor and oxidant exposure at a deposition temperature of $200{ }^{\circ} \mathrm{C}$. The $\mathrm{Al}_{2} \mathrm{O}_{3}$ films were deposited first, followed by a forming gas anneal (FGA) at $400{ }^{\circ} \mathrm{C}$. Subsequently, $\mathrm{TiO}_{2}$ was deposited and annealed in $\mathrm{O}_{2}$ at $300-400{ }^{\circ} \mathrm{C}$. Post- $\mathrm{TiO}_{2}$ deposition annealing was carried out in an $\mathrm{O}_{2}$ ambient in order to minimize the concentration of oxygen vacancies and obtain stoichiometric films. ${ }^{21}$

The passivation quality of the films was determined by the emitter saturation current density $\mathrm{J}_{0 \mathrm{e}}$ of the $\mathrm{p}^{+}$emitters, which was measured using the inductively coupled photoconductive decay technique. ${ }^{22}$ For the samples used for capacitance-voltage $(\mathrm{C}-\mathrm{V})$ and conductance measurements, $\mathrm{Al}_{2} \mathrm{O}_{3} / \mathrm{TiO}_{2}$ stack layers were deposited onto the front of the samples followed by a very thin $(\sim 2 \mathrm{~nm}) \mathrm{Al}_{2} \mathrm{O}_{3}$ capping layer. The deposition of a capping layer in top of the $\mathrm{TiO}_{2}$ was found to be necessary to obtain reliable $\mathrm{C}-\mathrm{V}$ measurement curves. Without a capping layer, the accumulation capacitance of $\mathrm{Al}_{2} \mathrm{O}_{3} / \mathrm{TiO}_{2}$ samples was generally found to be greater than the accumulation capacitance of samples with $\mathrm{Al}_{2} \mathrm{O}_{3}$ only, which is attributed to non-negligible conductivity of the $\mathrm{TiO}_{2}$ film or a diffusion of the evaporated aluminium contacts into the $\mathrm{TiO}_{2} .{ }^{23}$ GaIn contacts were formed on the rear of the samples. The interface characteristics of the MOS capacitors were evaluated by capacitance-voltage and conductance via small ac signal admittance measurement at frequencies ranging from $1 \mathrm{KHz}$ to $1 \mathrm{MHz}$ using a HP4284A Precision LCR meter.

\section{RESULTS AND DISCUSSION}

\section{A. Emitter saturation current density}

Figure 1 shows the emitter saturation current densities $\mathrm{J}_{0 \mathrm{e}}$ measured on samples after FGA $\left(\mathrm{Al}_{2} \mathrm{O}_{3}\right.$ only) or immediately after the subsequent $\mathrm{TiO}_{2}$ deposition. For the single layer $\mathrm{Al}_{2} \mathrm{O}_{3}$ films, a considerable increase in $\mathrm{J}_{0 \mathrm{e}}$ is observed for an $\mathrm{Al}_{2} \mathrm{O}_{3}$ thickness below $10 \mathrm{~nm}$. This result is consistent with those of Dingemans et al. ${ }^{24} \mathrm{~J}_{0 \mathrm{e}}$ on diffused surfaces characterizes recombination within the emitter and at the surface. Since the emitter profile is the same for all the samples and the deposition and post deposition treatment are not expected to influence the emitter, the changes in $\mathrm{J}_{0 \mathrm{e}}$ are attributed to changes in the contribution to $\mathrm{J}_{0 \mathrm{e}}$ from recombination at the sample surfaces $\mathrm{J}_{0 \mathrm{es}}$. $\mathrm{J}_{0 \mathrm{eS}}$ is influenced by changes in the interface defect density as well as the net charge in the passivation film, which influences the degree of field-effect passivation. However, the field-effect passivation is expected to be virtually unaffected by the thickness because the negative charges reside at the interface between $\mathrm{Si}$ and $\mathrm{Al}_{2} \mathrm{O}_{3}$ and the negative charge density is thus not significantly affected even for films with a thickness of $5 \mathrm{~nm} .^{25,26}$ The increase in $\mathrm{J}_{0 \mathrm{e}}$ for thin $\mathrm{Al}_{2} \mathrm{O}_{3}$ films is therefore attributed to a degradation of the chemical passivation for very thin films. Following $\mathrm{TiO}_{2}$ deposition, the same trend of higher $\mathrm{J}_{0 \mathrm{e}}$ for thin $\mathrm{Al}_{2} \mathrm{O}_{3}$ films is still observed, but the $\mathrm{J}_{0 \mathrm{e}}$ values are substantially lower, especially for thin $\mathrm{Al}_{2} \mathrm{O}_{3}$ below $10 \mathrm{~nm}$. As the $\mathrm{Al}_{2} \mathrm{O}_{3}$ thickness increases, the effect of the $\mathrm{TiO}_{2}$ film on passivation becomes weaker.

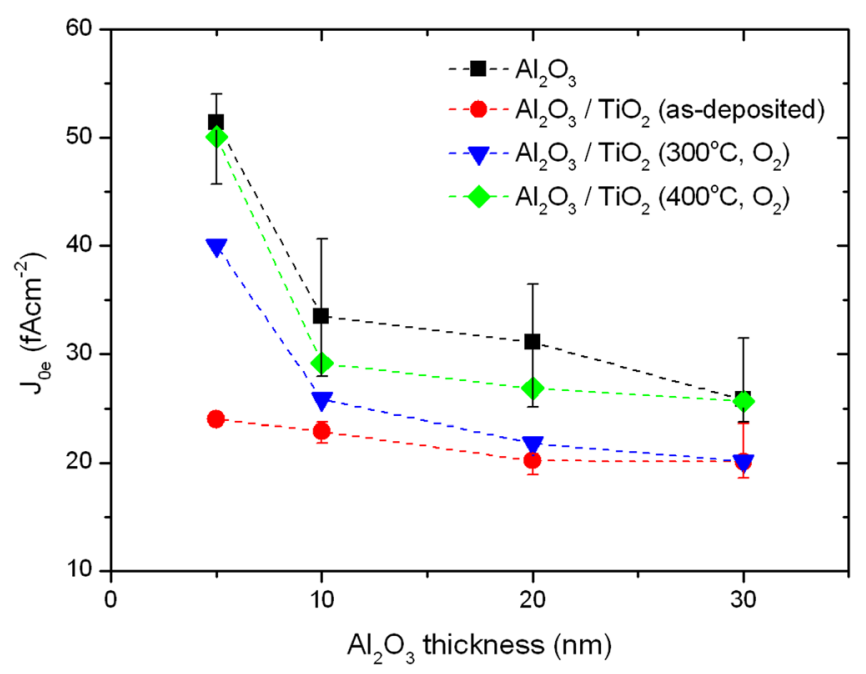

FIG. 1. Emitter saturation current density $\mathrm{J}_{0 \mathrm{e}}$ at a fixed injection level of $10^{16} \mathrm{~cm}^{-3}$ for $\mathrm{p}^{+} / \mathrm{n} / \mathrm{p}^{+}$symmetric lifetime samples passivated with $\mathrm{Al}_{2} \mathrm{O}_{3}$ films following various treatments: annealed at $400^{\circ} \mathrm{C}$ in forming gas (black squares); subsequent deposition of $50 \mathrm{~nm} \mathrm{TiO}_{2}$ (red circles); subsequent anneal in $\mathrm{O}_{2}$ for $30 \mathrm{~min}$ at $300^{\circ} \mathrm{C}$ (blue triangle) and at $400{ }^{\circ} \mathrm{C}$ (green inverted triangles), respectively. 


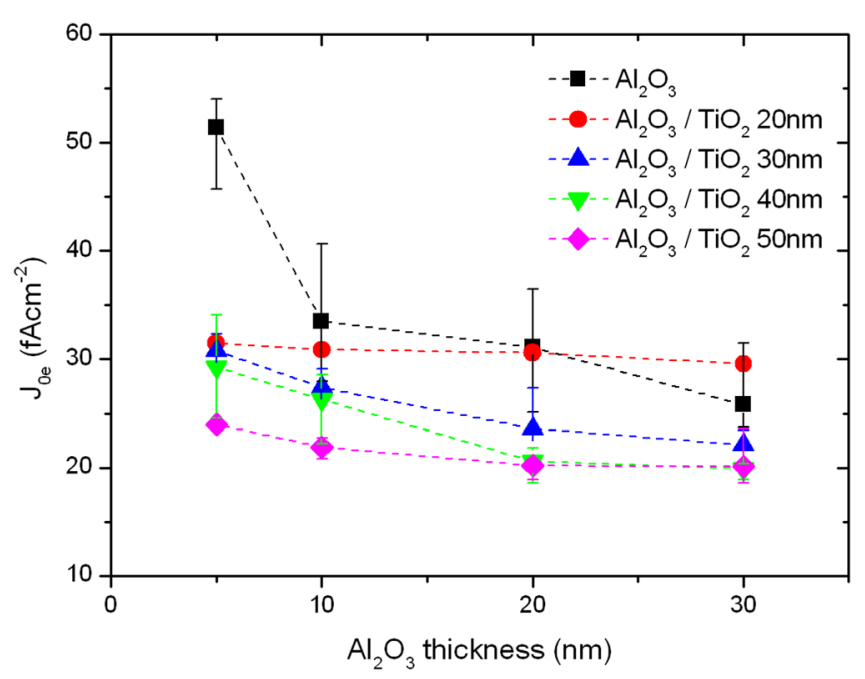

FIG. 2. Emitter saturation current density $\mathrm{J}_{0 \mathrm{e}}$ at a fixed injection level of $10^{16} \mathrm{~cm}^{-3}$ for $\mathrm{p}^{+} / \mathrm{n} / \mathrm{p}^{+}$symmetric lifetime samples passivated with $\mathrm{Al}_{2} \mathrm{O}_{3} / \mathrm{TiO}_{2}$ stacks with various $\mathrm{TiO}_{2}$ film thicknesses. Samples received a $400{ }^{\circ} \mathrm{C}, 30 \mathrm{~min}$ anneal in forming gas prior to $\mathrm{TiO}_{2}$ deposition, and a $300^{\circ} \mathrm{C}$ 30 min anneal in $\mathrm{O}_{2}$ after $\mathrm{TiO}_{2}$ deposition.

Although not shown here, it was confirmed that the improved passivation following $\mathrm{TiO}_{2}$ deposition is related to the $\mathrm{TiO}_{2}$ layer itself and not a result of the thermal budget the samples are exposed to during $\mathrm{TiO}_{2}$ deposition. Samples with $\mathrm{Al}_{2} \mathrm{O}_{3}$ films on which mock deposition were carried out (including simulation of the entire deposition process except of the pulsing of the $\mathrm{TiCl}_{4}$ ) displayed no significant change in surface passivation. Figure 1 also shows that annealing of the $\mathrm{TiO}_{2}$ film results in a degradation of the passivation; in the case of a $300^{\circ} \mathrm{C}$ anneal the degradation is slight while after a $400{ }^{\circ} \mathrm{C}$ anneal it is more significant and results in the $\mathrm{J}_{0 \mathrm{e}}$ values approaching those of the samples prior to $\mathrm{TiO}_{2}$ deposition.

Figure 2 shows results for the thickness dependence of the $\mathrm{J}_{0 \mathrm{e}}$ for $\mathrm{Al}_{2} \mathrm{O}_{3} / \mathrm{TiO}_{2}$ films. Regardless of $\mathrm{TiO}_{2}$ film thickness, a significant increase in $\mathrm{J}_{0 \mathrm{e}}$ is observed for $5 \mathrm{~nm}$ thick $\mathrm{Al}_{2} \mathrm{O}_{3}$ films compared to thicker $\mathrm{Al}_{2} \mathrm{O}_{3}$ layers. In general, an

(a)

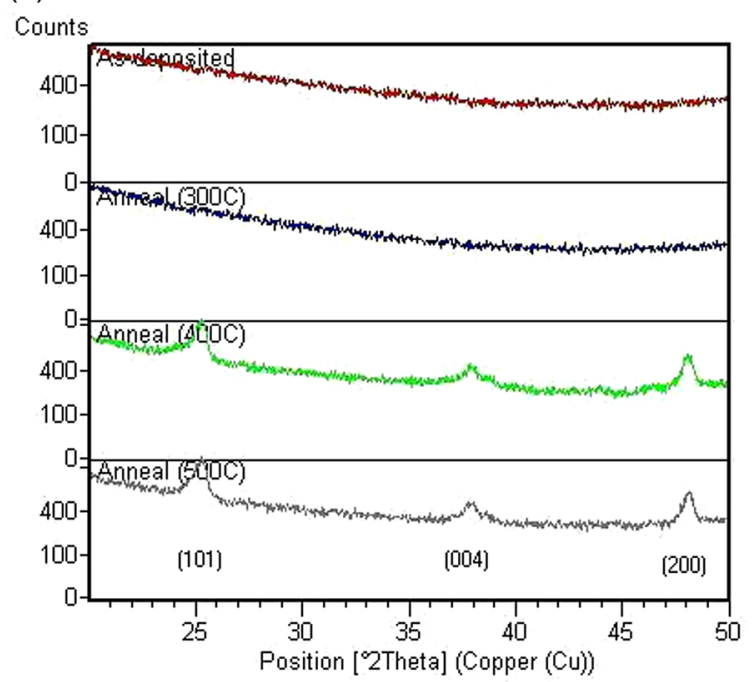

increase in $\mathrm{TiO}_{2}$ thickness improves the surface passivation up to a $\mathrm{TiO}_{2}$ thickness between 40 and $50 \mathrm{~nm}$. Importantly, $\mathrm{J}_{0 \mathrm{e}}$ values as low as $20 \mathrm{fA} \mathrm{cm}^{-2}$ can be obtained for an $\mathrm{Al}_{2} \mathrm{O}_{3}$ thickness of $20 \mathrm{~nm}$ and a $\mathrm{TiO}_{2}$ thickness of $\sim 50 \mathrm{~nm}$. This $\mathrm{TiO}_{2}$ layer thickness is very close to the optimal $\mathrm{TiO}_{2}$ thickness for an antireflection coating for a planar encapsulated cell given typical values of the refractive indices of $\mathrm{Al}_{2} \mathrm{O}_{3}$ (1.6) and $\mathrm{TiO}_{2}$ (2.4).

\section{B. $\mathrm{TiO}_{2}$ crystallinity}

In order to understand the reasons behind the improvement in passivation following $\mathrm{TiO}_{2}$ deposition, the material and interface properties were investigated in more detail. Figure 3 shows the results of X-ray diffractometry (XRD) measurements on $\mathrm{Al}_{2} \mathrm{O}_{3} / \mathrm{TiO}_{2}$. It can be seen that $\mathrm{TiO}_{2}$ layers in as-deposited $\mathrm{Al}_{2} \mathrm{O}_{3} / \mathrm{TiO}_{2}$ stacks are amorphous, even for a $\mathrm{TiO}_{2}$ thickness of $50 \mathrm{~nm}$ (not shown in the figure). This is in contrast to the results of Aarik et al. ${ }^{27,28}$ who found that $\mathrm{TiO}_{2}$ films deposited at temperatures below $140{ }^{\circ} \mathrm{C}$ were amorphous while those deposited over $165^{\circ} \mathrm{C}$ and having sufficient thickness from $15 \mathrm{~nm}$ showed diffraction patterns characteristic of polycrystalline $\mathrm{TiO}_{2}$ on all used substrates. Figure 3 also shows that following annealing the $\mathrm{TiO}_{2}$ film became polycrystalline (anatase phase), with the transition from amorphous to crystalline phases depending on both the anneal temperature and layer thickness. The comparatively high anneal temperature required for crystallization suggests that grain growth is suppressed by the $\mathrm{Al}_{2} \mathrm{O}_{3}$ interlayer not only during the deposition process but also during the annealing process.

A question that immediately arises from these observations is to what extent the crystallization of the $\mathrm{TiO}_{2}$ films may impact the stack passivation properties or correlate with observed changes in the passivation. At present, the data are insufficient for a conclusive answer; however, in Fig. 2, no degradation in surface passivation was observed for thick (50 nm) $\mathrm{TiO}_{2}$ films on $10 \mathrm{~nm} \mathrm{Al}_{2} \mathrm{O}_{3}$ following a $300{ }^{\circ} \mathrm{C}$ anneal; compared to thinner $\mathrm{TiO}_{2}$ films. Since $50 \mathrm{~nm} \mathrm{TiO}_{2}$ is

(b)

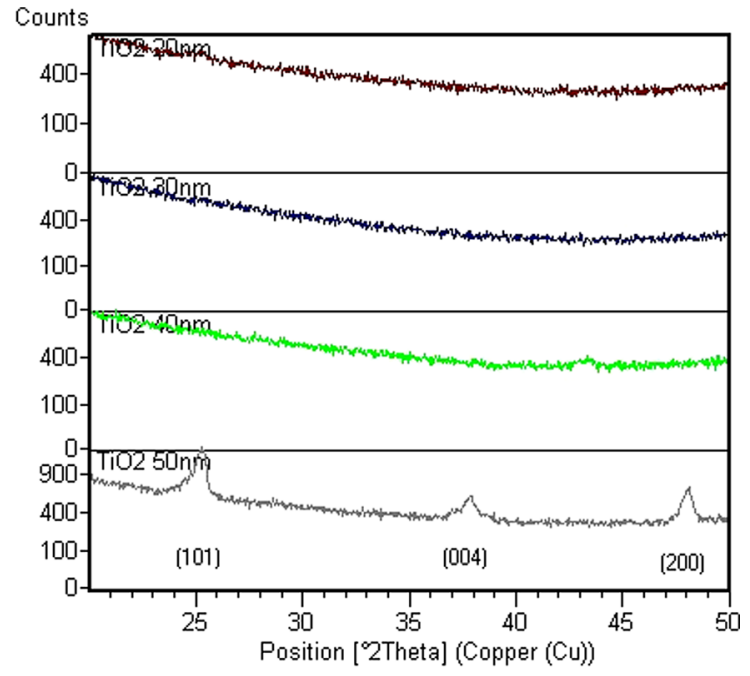

FIG. 3. XRD patterns of $\mathrm{TiO}_{2}$ films deposited on $\mathrm{Si}$ substrates covered with $10 \mathrm{~nm} \mathrm{Al}_{2} \mathrm{O}_{3}$ which was annealed at $400^{\circ} \mathrm{C}$ in forming gas (a) $30 \mathrm{~nm}$ TiO $\mathrm{S}_{2}$ subsequently annealed at different temperatures up to $500^{\circ} \mathrm{C}$ for $30 \mathrm{~min}$, and (b) $\mathrm{TiO}_{2}$ films with different thicknesses annealed at $300^{\circ} \mathrm{C}$ for $30 \mathrm{~min}$. 


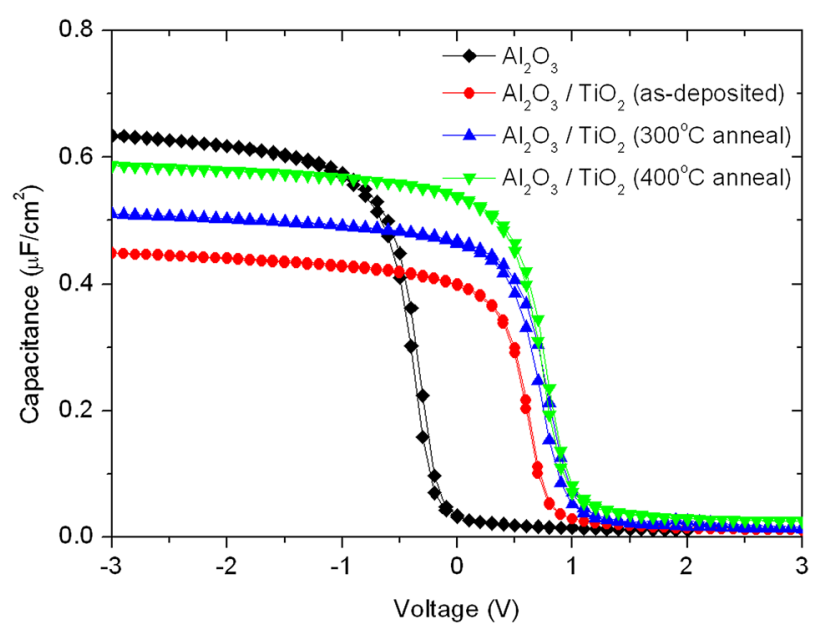

FIG. 4. High frequency ( $1 \mathrm{MHz}$ ) C-V characteristics of $10 \mathrm{~nm} \mathrm{Al}_{2} \mathrm{O}_{3} / 30 \mathrm{~nm}$ $\mathrm{TiO}_{2}$ stack layers. The $\mathrm{Al}_{2} \mathrm{O}_{3}$ films were annealed at $400{ }^{\circ} \mathrm{C}$ for $30 \mathrm{~min}$ in forming gas prior to $\mathrm{TiO}_{2}$ deposition or $\mathrm{C}-\mathrm{V}$ measurement. Post $\mathrm{TiO}_{2}$ deposition anneal conditions were for $30 \mathrm{~min}$ in $\mathrm{O}_{2}$ at either 300 or $400{ }^{\circ} \mathrm{C}$ as indicated in the legend. $\mathrm{A} \sim 2 \mathrm{~nm} \mathrm{Al}_{2} \mathrm{O}_{3}$ film was deposited on top of the $\mathrm{TiO}_{2}$ film prior to $\mathrm{C}-\mathrm{V}$ measurements.

observed to result in the formation of the crystalline phase in Fig. 3(b), there does not seem to be a direct correlation between the two; in other words, crystallization of the $\mathrm{TiO}_{2}$ films does not of itself appear to cause degradation in surface passivation.

\section{Charge trapping density}

Figure 4 shows the high frequency $\mathrm{C}-\mathrm{V}$ characteristics of $\mathrm{Al}_{2} \mathrm{O}_{3}$ and $\mathrm{TiO}_{2}$ stack layers before and after $\mathrm{TiO}_{2}$ deposition and annealing. Capacitance was measured at $1 \mathrm{MHz}$ as a function of gate voltage and the capacitor was swept from inversion to accumulation and back to determine the amount of hysteresis. A small amount of hysteresis can be observed in the $\mathrm{C}-\mathrm{V}$ curve of the $\mathrm{Al}_{2} \mathrm{O}_{3}$ single layer, indicating that application of a positive gate voltage caused electron injection into the oxide from the substrate while during a sweep from positive to negative voltages the trapped electrons can be ejected from the oxide back into the substrate. Following $\mathrm{TiO}_{2}$ deposition, there is a decrease in the $\mathrm{C}-\mathrm{V}$ hysteresis, indicating a reduction of the density of carrier-trapping defect sites that are responsible for the hysteresis. After annealing, there is increase in the hysteresis as crystallization of the initially amorphous $\mathrm{TiO}_{2}$ films occurs. This suggests that introduction of grain boundaries or crystal/amorphous boundaries may increase the density of such carrier-trapping defect sites.

The flatband voltage shift $\left(\Delta \mathrm{V}_{\mathrm{FB}}\right)$ characterizing the hysteresis of the $\mathrm{C}-\mathrm{V}$ curves of Fig. 4 was used to estimate the charge trapping density $\mathrm{Q}_{\text {ot }}$ of the $\mathrm{Al}_{2} \mathrm{O}_{3}$ films in the $\mathrm{Al}_{2} \mathrm{O}_{3} / \mathrm{TiO}_{2}$ stacks, using the relation

$$
Q_{o t}=C_{o x} \times \frac{\Delta V_{F B}}{q}
$$

for the calculation of $\mathrm{Q}_{\mathrm{ot}}{ }^{29}{ }^{29}$ where $\mathrm{q}$ is the electronic charge and $\mathrm{C}_{\mathrm{ox}}$ is the flatband capacitance. In spite of the limitation that $\mathrm{Q}_{\mathrm{ot}}$ is influenced by the measurement parameters, such as the magnitude and direction of the sweep gate voltage and sweep time, the extracted values allow comparison of the film defect density following various treatments. As can be seen in Table I, the $\mathrm{Al}_{2} \mathrm{O}_{3} / \mathrm{TiO}_{2}$ stack layer without subsequent anneal has a significantly lower $\mathrm{Q}_{\mathrm{ot}}$ than the $\mathrm{Al}_{2} \mathrm{O}_{3}$ single layer. However, $\mathrm{Q}_{\text {ot }}$ values of $\mathrm{Al}_{2} \mathrm{O}_{3} / \mathrm{TiO}_{2}$ increase up to that of $\mathrm{Al}_{2} \mathrm{O}_{3}$ single layer as anneal temperature increases.

\section{Fixed charge density}

Figure 5(a) shows high frequency $\mathrm{C}-\mathrm{V}$ curves for $\mathrm{Al}_{2} \mathrm{O}_{3} / \mathrm{TiO}_{2}$ stacks with different $\mathrm{TiO}_{2}$ thicknesses, while Fig. 5(b) shows the values of the dielectric constant $\mathrm{k}_{\mathrm{TiO} 2}$ of the $\mathrm{TiO}_{2}$ films of the stacks. The values of $\mathrm{k}_{\mathrm{TiO} 2}$ were determined by assuming that the $\mathrm{Al}_{2} \mathrm{O}_{3} / \mathrm{TiO}_{2}$ stack layer behaves as two capacitors in series, so that the total oxide capacitance $\mathrm{C}_{\mathrm{ox}}$ is given by

$$
\frac{1}{C_{O x}}=\frac{1}{\varepsilon_{0} A}\left(\frac{d_{A l 2 O 3}}{k_{A l 2 O 3}}+\frac{d_{T i O 2}}{k_{T i O 2}}\right)
$$

where $\varepsilon_{0}$ is the permittivity of free space and $\mathrm{k}_{\mathrm{Al} 2 \mathrm{O} 3}, \mathrm{k}_{\mathrm{TiO} 2}$, $\mathrm{d}_{\mathrm{Al} 2 \mathrm{O} 3}$, and $\mathrm{d}_{\mathrm{TiO} 2}$ are the dielectric constants and thicknesses of the $\mathrm{Al}_{2} \mathrm{O}_{3}$ and $\mathrm{TiO}_{2}$ films, respectively. The value of $\mathrm{k}_{\mathrm{Al} 2 \mathrm{O} 3}$ is assumed to be constant and was determined from the accumulation capacitance of the single $\mathrm{Al}_{2} \mathrm{O}_{3}$ film following 30 min forming gas anneal, which yielded $\mathrm{k}_{\mathrm{Al} 2 \mathrm{O} 3}$ of 7.3 , in good agreement with published values.

The results of Fig. 5(a) indicate that as-deposited $\mathrm{TiO}_{2}$ films thicker than $\sim 10 \mathrm{~nm}$ have a relatively constant $\mathrm{k}_{\mathrm{TiO} 2}$ in the range of 40 to $60 . \mathrm{TiO}_{2}$ films annealed at $300{ }^{\circ} \mathrm{C}$ display a similar value of $\mathrm{k}_{\mathrm{TiO} 2}$ except for the $50 \mathrm{~nm}$ thick film, for which $\mathrm{k}$ is substantially larger; corresponding to the onset of crystallization as shown in Fig. 3. $\mathrm{TiO}_{2}$ films annealed at $400{ }^{\circ} \mathrm{C}$ experienced a dramatic increase in $\mathrm{k}_{\mathrm{TiO} 2}(>100)$ with respect to the as-deposited film. The exact value of $\mathrm{k}_{\mathrm{TiO} 2}$ in these films as determined from the $\mathrm{C}-\mathrm{V}$ data is expected to be quite inaccurate; all that can be said with some certainty is that the value of $\mathrm{k}_{\mathrm{TiO} 2}$ are very large.

When all the charge is assumed to be located at the $\mathrm{Si} / \mathrm{Al}_{2} \mathrm{O}_{3}$ interface, the effective fixed charge density $\left(\mathrm{Q}_{\mathrm{eff}}\right)$ of the $\mathrm{Al}_{2} \mathrm{O}_{3} / \mathrm{TiO}_{2}$ stack layers was determined from $\mathrm{C}-\mathrm{V}$ measurements. Table II shows the $\mathrm{Q}_{\text {eff }}$ values measured on $\mathrm{Al}_{2} \mathrm{O}_{3} / \mathrm{TiO}_{2}$ stack layers as a function of post-anneal temperature. The results are given for both $\mathrm{Al}_{2} \mathrm{O}_{3}$ single and $\mathrm{Al}_{2} \mathrm{O}_{3} / \mathrm{TiO}_{2}$ stack layers. Compared to $\mathrm{Al}_{2} \mathrm{O}_{3}$ single layer, the $\mathrm{Al}_{2} \mathrm{O}_{3} / \mathrm{TiO}_{2}$ stack layers show a higher density of

\begin{tabular}{|c|c|c|c|c|}
\hline & $\mathrm{Al}_{2} \mathrm{O}_{3}{ }^{\mathrm{a}}$ & $\mathrm{Al}_{2} \mathrm{O}_{3}^{\mathrm{a}} / \mathrm{TiO}_{2}$ (as-deposited) & $\mathrm{Al}_{2} \mathrm{O}_{3}{ }^{\mathrm{a}} / \mathrm{TiO}_{2}\left(\text { annealed at } 300^{\circ} \mathrm{C}\right)^{\mathrm{b}}$ & $\mathrm{Al}_{2} \mathrm{O}_{3}{ }^{\mathrm{a}} / \mathrm{TiO}_{2}\left(\text { annealed at } 400^{\circ} \mathrm{C}\right)^{\mathrm{b}}$ \\
\hline $\mathrm{Q}_{\mathrm{ot}}\left(\mathrm{cm}^{-2}\right)$ & $4.9 \times 10^{11}$ & $8.2 \times 10^{10}$ & $1.8 \times 10^{11}$ & $3.7 \times 10^{11}$ \\
\hline
\end{tabular}

TABLE I. Charge trapping density $\mathrm{Q}_{\mathrm{ot}}$ of $10 \mathrm{~nm} \mathrm{Al}_{2} \mathrm{O}_{3}$ and $10 \mathrm{~nm} \mathrm{Al}_{2} \mathrm{O}_{3} / 30 \mathrm{~nm} \mathrm{TiO}{ }_{2}$ stack layers.

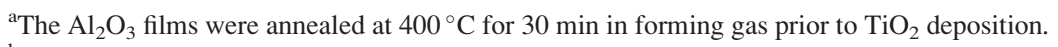

${ }^{\mathrm{b}} \mathrm{Post} \mathrm{TiO}_{2}$ deposition anneal conditions were for $30 \mathrm{~min}$ in $\mathrm{O}_{2}$ at as indicated. 

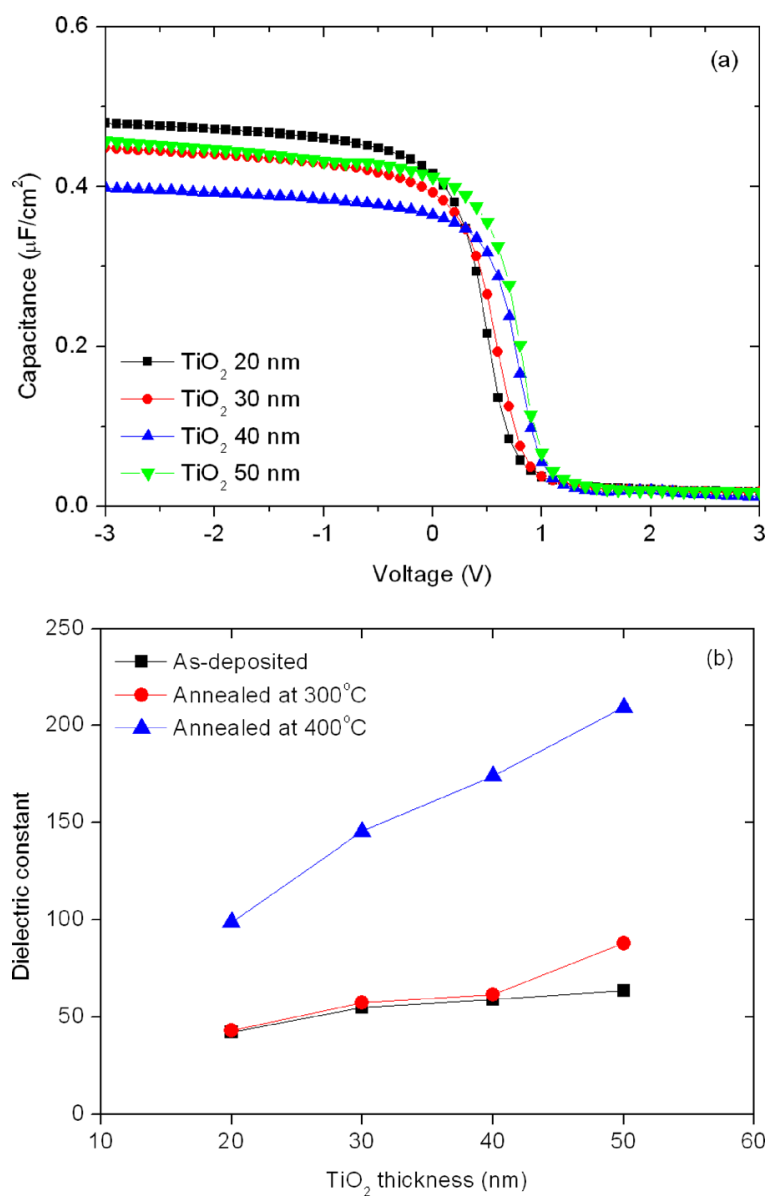

FIG. 5. High frequency (1 MHz) C-V characteristics of $10 \mathrm{~nm} \mathrm{Al}_{2} \mathrm{O}_{3} / \mathrm{TiO}_{2}$ stack layers. The $\mathrm{Al}_{2} \mathrm{O}_{3}$ films were annealed at $400{ }^{\circ} \mathrm{C}$ for $30 \mathrm{~min}$ in forming gas prior to $\mathrm{TiO}_{2}$ deposition. Post $\mathrm{TiO}_{2}$ deposition anneal conditions were for $30 \mathrm{~min}$ in $\mathrm{O}_{2}$ at $300^{\circ} \mathrm{C}$. A $\sim 2 \mathrm{~nm} \mathrm{Al}_{2} \mathrm{O}_{3}$ capping layer was deposited on top of the $\mathrm{TiO}_{2}$ film prior to $\mathrm{C}-\mathrm{V}$ measurements. (b) Thickness dependencies of the relative dielectric constant of as-deposited and annealed $\mathrm{TiO}_{2}$ films on $\mathrm{Al}_{2} \mathrm{O}_{3}$.

negative fixed charge of $4.3 \times 10^{12} \mathrm{~cm}^{-2}$. The $\mathrm{Al}_{2} \mathrm{O}_{3} / \mathrm{TiO}_{2}$ stack layers show increasing $Q_{\text {eff }}$ for higher anneal temperature.

To distinguish the contribution of $\mathrm{Al}_{2} \mathrm{O}_{3}$ and $\mathrm{TiO}_{2}$ layers to effective fixed charge density, the variation in $\mathrm{V}_{\mathrm{FB}}$ of the $\mathrm{Al}_{2} \mathrm{O}_{3} / \mathrm{TiO}_{2}$ stack layers as a function of the film thickness and dielectric constant are shown in Fig. 6 in the as-deposited and annealed states. The $\mathrm{V}_{\mathrm{FB}}-\left(\mathrm{d}_{\mathrm{TiO} 2} / \mathrm{k}_{\mathrm{TiO} 2}\right)$ data have been fitted with a straight line consistent with the solution to Poisson's equation using the following equation: ${ }^{30}$

$$
V_{F B}=\Phi_{M S}-\frac{q}{\varepsilon_{0}}\left[Q_{A l 2 O 3} \frac{d_{A l 2 O 3}}{k_{A l 2 O 3}}+\left(Q_{A l 2 O 3}+Q_{T i O 2}\right) \frac{d_{T i O 2}}{k_{T i O 2}}\right],
$$

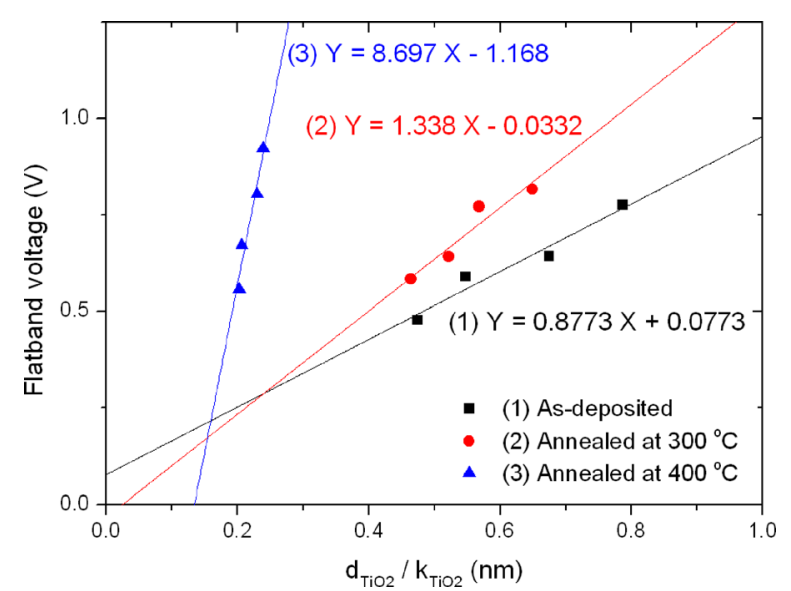

FIG. 6. Flatband voltage of $10 \mathrm{~nm} \mathrm{Al}_{2} \mathrm{O}_{3} / \mathrm{TiO}_{2}$ stacks as a function of the $\mathrm{d}_{\mathrm{TiO} 2} / \mathrm{k}_{\mathrm{TiO} 2}$ in the as-deposited and post- $\mathrm{TiO}_{2}$ annealed states, respectively.

where $\Phi_{\mathrm{MS}}$ is the metal-semiconductor work function difference $(0.87 \mathrm{eV}), \mathrm{q}$ is the electronic charge, assuming that $\mathrm{Q}_{\mathrm{Al2O} 3}$ is the charge located at the $\mathrm{Si}-\mathrm{Al}_{2} \mathrm{O}_{3}$ interface, and $\mathrm{Q}_{\mathrm{TiO} 2}$ is the charge located at the internal dielectric interface between the $\mathrm{Al}_{2} \mathrm{O}_{3}$ and $\mathrm{TiO}_{2}$ layers. From the y-intercept and slopes, $\mathrm{Q}_{\mathrm{Al} 2 \mathrm{O} 3}$ and $\mathrm{Q}_{\mathrm{TiO} 2}$ can be estimated, respectively, by a least-squares linear fit. In case of $\mathrm{Al}_{2} \mathrm{O}_{3}$ single layer once annealed at $400{ }^{\circ} \mathrm{C}$, additional $300-400^{\circ} \mathrm{C}$ anneal does not have an impact on $\mathrm{Al}_{2} \mathrm{O}_{3}$ passivation, so the $\mathrm{V}_{\mathrm{FB}}$ of single $\mathrm{Al}_{2} \mathrm{O}_{3}$ layer annealed at $400{ }^{\circ} \mathrm{C}$ is also included.

The data in Fig. 6 clearly indicate the presence of negative charge not just at the $\mathrm{Al}_{2} \mathrm{O}_{3} / \mathrm{Si}$ interface but also within the $\mathrm{TiO}_{2}$ film or (more likely) at the $\mathrm{Al}_{2} \mathrm{O}_{3} / \mathrm{TiO}_{2}$ interface. Figure 7 shows the charge densities extracted from the data of Fig. 6 assuming an additional sheet of charge located at the $\mathrm{Al}_{2} \mathrm{O}_{3} / \mathrm{TiO}_{2}$ interface. As compared to these results, the anneal exhibits mostly changes in slope, indicating the fixed charge at $\mathrm{Al}_{2} \mathrm{O}_{3} / \mathrm{TiO}_{2}$ interface changes. As a result, the fixed charge density of $\mathrm{Al}_{2} \mathrm{O}_{3} / \mathrm{TiO}_{2}$ stack layers can be obtained as shown in Fig. 7. A higher negative charge density of $4.9 \times 10^{12} \mathrm{~cm}^{-2}$ is obtained for as-deposited $\mathrm{TiO}_{2}$ layer, compared to single thin $\mathrm{Al}_{2} \mathrm{O}_{3}$ layer. As anneal temperature increases to $400^{\circ} \mathrm{C}, \mathrm{Q}_{\mathrm{TiO} 2}$ increases significantly. As a result, compared to the trend of the effective fixed charge density in Table II, the effect of charge distributed throughout the $\mathrm{Al}_{2} \mathrm{O}_{3} / \mathrm{TiO}_{2}$ stack layer on the passivation is more limited than that of the charge at $\mathrm{Si} / \mathrm{Al}_{2} \mathrm{O}_{3}$ interface.

\section{E. Interface trap density}

It is difficult to measure quasi-static capacitance of high-k $\mathrm{TiO}_{2}$ due to relatively high leakage current, resulting in the inaccurate interface trap density determination.

TABLE II. Effective fixed charge density $\mathrm{Q}_{\text {eff }}$ of $10 \mathrm{~nm} \mathrm{Al} \mathrm{O}_{3}$ and $10 \mathrm{~nm} \mathrm{Al}_{2} \mathrm{O}_{3} / 30 \mathrm{~nm} \mathrm{TiO} \mathrm{Ti}_{2}$ stack layers.

\begin{tabular}{ccccc}
\hline \hline & $\mathrm{Al}_{2} \mathrm{O}_{3}{ }^{\mathrm{a}}$ & $\mathrm{Al}_{2} \mathrm{O}_{3}{ }^{\mathrm{a}} / \mathrm{TiO}_{2}$ (as-deposited) & $\mathrm{Al}_{2} \mathrm{O}_{3}{ }^{\mathrm{a}} / \mathrm{TiO}_{2}$ (annealed at $\left.300^{\circ} \mathrm{C}\right)^{\mathrm{b}}$ & $\mathrm{Al}_{2} \mathrm{O}_{3}{ }^{\mathrm{a}} / \mathrm{TiO}_{2}\left(\text { annealed at } 400^{\circ} \mathrm{C}\right)^{\mathrm{b}}$ \\
\hline $\mathrm{Q}_{\text {eff }}\left(\mathrm{cm}^{-2}\right)$ & $2.3 \times 10^{12}$ & $4.5 \times 10^{12}$ & $5.5 \times 10^{12}$ & $6.4 \times 10^{12}$ \\
\hline \hline
\end{tabular}

${ }^{\mathrm{a}} \mathrm{The} \mathrm{Al}_{2} \mathrm{O}_{3}$ films were annealed at $400{ }^{\circ} \mathrm{C}$ for $30 \mathrm{~min}$ in forming gas prior to $\mathrm{TiO}_{2}$ deposition.

${ }^{\mathrm{b}} \mathrm{Post} \mathrm{TiO}_{2}$ deposition anneal conditions were for $30 \mathrm{~min}$ in $\mathrm{O}_{2}$ at as indicated. 


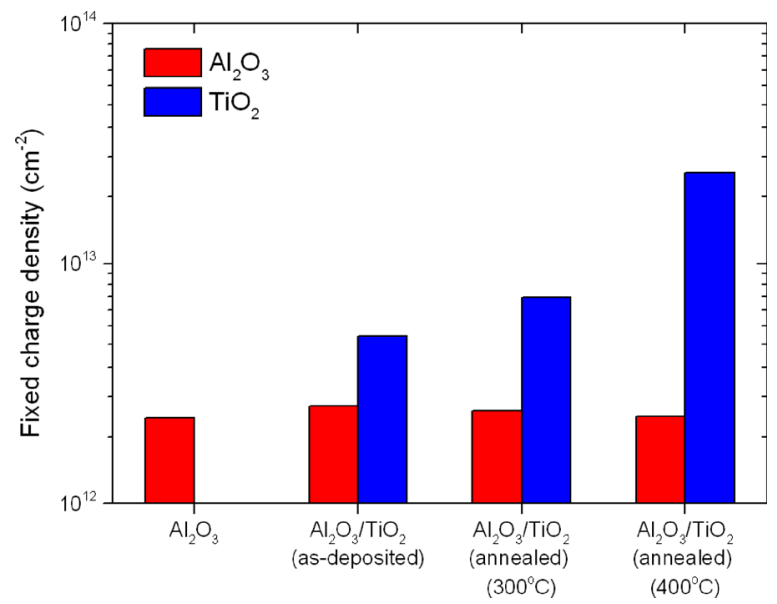

FIG. 7. Relationship between the negative fixed charge density of $\mathrm{Al}_{2} \mathrm{O}_{3}$ and $\mathrm{TiO}_{2}$ layer and the negative charge in the $\mathrm{TiO}_{2}$ on $10 \mathrm{~nm} \mathrm{Al} \mathrm{O}_{3}$.

Although the high-frequency Terman method provides a rough evaluation of interface trap density, which is based on the extraction of the experimental surface potential versus gate voltage, ${ }^{31}$ it becomes less sensitive with increasing capacitance since the voltage shift is inversely proportional to the insulator capacitance. ${ }^{30}$ For the extraction of more reliable interface trap density, the conductance method is more suitable because the surface potential fluctuation is a function of energy in the depletion region of the band gap. To determine an accurate $\mathrm{D}_{\mathrm{it}}$, the insulator capacitance and series resistance effects are removed from the measured conductance $G_{m}$ peak using the following relation: ${ }^{32}$

$$
G_{p}=\frac{\omega^{2} C_{o x}^{2} G_{m}}{G_{m}^{2}+\omega^{2}\left(C_{o x}-C_{m}\right)^{2}},
$$

where $G_{p}$ is the corrected conductance, $\omega$ is the angular frequency and $\mathrm{C}_{\mathrm{m}}$ is the measured capacitance. The $\mathrm{D}_{\mathrm{it}}$ is calculated from $^{32}$

$$
D_{i t}=\left(\frac{G_{p}}{\omega}\right)_{f_{p}} \frac{1}{q f_{D}\left(\sigma_{s}\right) A}
$$

where $\mathrm{G}_{\mathrm{p}} / \omega$ is the corrected conductance loss, $\mathrm{f}_{\mathrm{p}}$ is the frequency corresponding to the peak value of conductance loss, $q$ is the electronic charge, $f_{D}$ is the universal function of standard deviation of band bending $\sigma_{\mathrm{s}}$, and $\mathrm{A}$ is an area of electrode. The $f_{D}$ value used for our samples is $0.402 .{ }^{33}$ The $\mathrm{D}_{\mathrm{it}}$ for the conductance loss values of $3.3 \mathrm{pF}$ is found to be approximately $1.2 \times 10^{10} \mathrm{eV}^{-1} \mathrm{~cm}^{-2}$. It should be noted that the $\mathrm{D}_{\text {it }}$ at midgap determined by the high-frequency $\mathrm{C}-\mathrm{V}$ method consisting of contributions from the oxide and interface traps shows much higher value of $10^{13} \mathrm{eV}^{-1} \mathrm{~cm}^{-2}$, showing higher inaccuracies compared to the conductance method.

$\mathrm{G}_{\mathrm{p}} / \omega$ is plotted in Fig. 8(a) as a function of frequency. Figure 8(b) shows the $\mathrm{D}_{\mathrm{it}}$ at midgap for the $\mathrm{Al}_{2} \mathrm{O}_{3} / \mathrm{TiO}_{2}$ stack layers as obtained by the conductance method. With a value of $1.1 \times 10^{10} \mathrm{eV}^{-1} \mathrm{~cm}^{-2}$ at midgap, the $\mathrm{D}_{\mathrm{it}}$ of the as-deposited $\mathrm{TiO}_{2}$ on $\mathrm{Al}_{2} \mathrm{O}_{3}$ is very low, and an order of
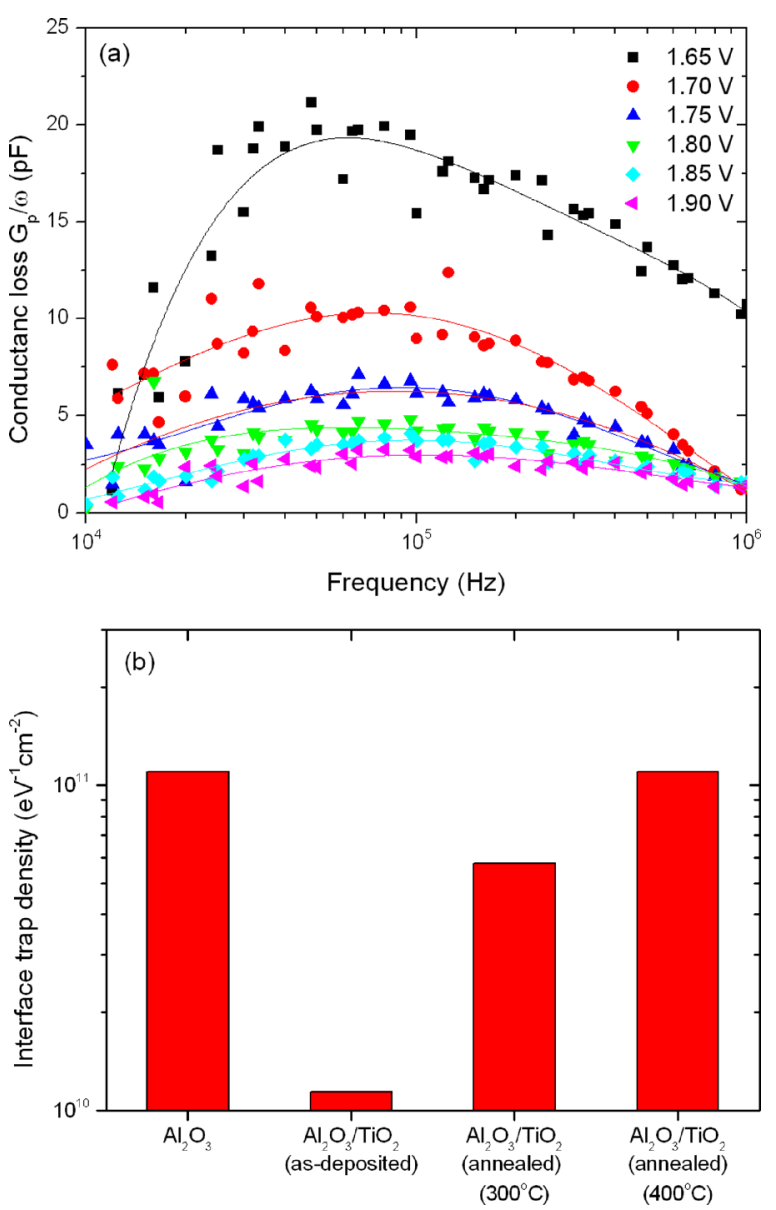

FIG. 8. (a) The measured conductance loss with frequency plot of $10 \mathrm{~nm}$ $\mathrm{Al}_{2} \mathrm{O}_{3}$ (annealed at $400{ }^{\circ} \mathrm{C}$ in forming gas) $/ 30 \mathrm{~nm} \mathrm{TiO}$ (as-deposited) as a function of gate voltage near the midgap, and (b) interface trap densities determined by the conductance method.

magnitude of lower than that of $\mathrm{Al}_{2} \mathrm{O}_{3}$ only passivated sample. However, as the post- $\mathrm{TiO}_{2}$ annealing temperature increases, $D_{i t}$ increases again and reaches a value of $1.1 \times 10^{11} \mathrm{eV}^{-1} \mathrm{~cm}^{-2}$ at midgap following a $400^{\circ} \mathrm{C}$ anneal, which is the almost same as that of only $\mathrm{Al}_{2} \mathrm{O}_{3}$-passivated sample.

On the basis of the above results, we can consider the possible reasons for the improvement in $\mathrm{J}_{0 \mathrm{e}}$ following $\mathrm{TiO}_{2}$ deposition as shown in Figs. 1 and 2. As already mentioned, surface passivation is determined by the degree of field effect passivation as well as chemical passivation. The results indicate that the negative charge in the film increases following $\mathrm{TiO}_{2}$ deposition. Empirically, the degree of field effect passivation is generally found to saturate at a charge density of around $5 \times 10^{12} \mathrm{~cm}^{-2} \cdot{ }^{34}$ Since the charge density in the $\mathrm{Al}_{2} \mathrm{O}_{3}$ film is well below this level, a significant improvement in field effect and surface passivation is expected as a result of the additional charge. The origin of the additional negative charge is not clear and requires further investigation.

As shown in Fig. 8(b), the deposition of $\mathrm{TiO}_{2}$ also results in a significant reduction in $\mathrm{D}_{\mathrm{it}}$, which indicates an improvement in the chemical passivation of interface states and is very likely to also be a reason for the improved surface passivation. 
An interesting question is why $\mathrm{D}_{\mathrm{it}}$ improves following $\mathrm{TiO}_{2}$ deposition. One possible reason (and the reason most often cited for improvements in $\mathrm{D}_{\mathrm{it}}$ following treatments of dielectric layers) is the improved passivation of interface defects with atomic $\mathrm{H}$. In other words, the deposition of $\mathrm{TiO}_{2}$ may result in the release of atomic $\mathrm{H}$ which diffused through the $\mathrm{TiO}_{2}$ and $\mathrm{Al}_{2} \mathrm{O}_{3}$ films to passivate interface defects. For example, Veith et al. demonstrated that the passivation quality of thin thermal $\mathrm{ALD}-\mathrm{Al}_{2} \mathrm{O}_{3}$ can be improved using a-SiN $\mathrm{N}_{\mathrm{x}} \mathrm{H}$ as a capping layer, which might be because of the hydrogenation of interface states. ${ }^{35}$ The deposition of a-SiN $: \mathrm{H}$ at a temperature of $400^{\circ} \mathrm{C}$ for several minutes has an effect similar to a short anneal. The $\mathrm{H}$ content in the bulk of $\mathrm{TiO}_{2}$ films deposited at around $200{ }^{\circ} \mathrm{C}$ has been found to be relatively low (about 0.4 atom \%), ${ }^{36}$ but it is possible that hydrogen is released during the layer-by-layer deposition of as a result of the reaction between surface hydroxyl groups and the titanium precursor $\mathrm{TiCl}_{4} \cdot{ }^{35-37}$ Dingemans et al. found that deposition of a $\mathrm{TiO}_{2}$ capping layer did not lead to higher level of passivation for $\mathrm{SiO}_{2}$ passivated silicon. ${ }^{38}$ Since atomic hydrogen is beneficial to the passivation of silicon by $\mathrm{SiO}_{2}$ (as observed following a so-called anneal treatment), ${ }^{7}$ the release of significant quantities of atomic $\mathrm{H}$ during the deposition process would be expected to improve $\mathrm{SiO}_{2}$ passivation. It must be noted that, however, Dingemans et al. used a different Ti precursor than used in our work, so the absence of improved passivation in their case is not conclusive evidence against the role of atomic $\mathrm{H}$ in the improved passivation observed in our work. However, defect passivation by atomic $\mathrm{H}$ does not seem to be a likely cause of the improved passivation for another reason, namely that the rate of diffusion of atomic $\mathrm{H}$ through $\mathrm{Al}_{2} \mathrm{O}_{3}$ at the deposition temperature of $200{ }^{\circ} \mathrm{C}$ is likely to be too low to be effective. Dingemans et al. measured the rate of effusion of $\mathrm{He}$ atoms in $\mathrm{Al}_{2} \mathrm{O}_{3}$ films as a function of both $\mathrm{Al}_{2} \mathrm{O}_{3}$ deposition and anneal temperature. For films deposited around $200{ }^{\circ} \mathrm{C}$, the onset of effusion did not occur until anneal temperatures of around $300{ }^{\circ} \mathrm{C} .{ }^{39}$ If atomic $\mathrm{H}$ is not the cause for the improvement in surface passivation, one may speculate that deposition of $\mathrm{TiO}_{2}$ may result in some reconstruction of the $\mathrm{Si} / \mathrm{Al}_{2} \mathrm{O}_{3}$ interface region, perhaps as a result of changed interface stress. However, at this stage, there is no evidence for such a hypothesis.

\section{CONCLUSIONS}

We studied the surface passivation of $\mathrm{Al}_{2} \mathrm{O}_{3} / \mathrm{TiO}_{2}$ stack layers as a function of $\mathrm{TiO}_{2}$ layer thickness and for different post-deposition anneals. For the single $\mathrm{Al}_{2} \mathrm{O}_{3}$ layers, $\mathrm{J}_{0 \mathrm{e}}$ was found to increase strongly for an $\mathrm{Al}_{2} \mathrm{O}_{3}$ layer thickness below $10 \mathrm{~nm}$. Significantly enhanced passivation was observed following deposition of $\mathrm{TiO}_{2}$ on thin $\mathrm{Al}_{2} \mathrm{O}_{3}$ passivated $\mathrm{Si}$ surfaces. Measurements of the effective fixed charge density in the stack revealed that $\mathrm{TiO}_{2}$ deposition increases $\mathrm{Q}_{\text {eff. }}$. Further, the $\mathrm{Al}_{2} \mathrm{O}_{3} / \mathrm{TiO}_{2}$ stack layers yield a high level of chemical passivation after $\mathrm{TiO}_{2}$ deposition due to a low interface defect density, which increases with anneal temperature. Improved chemical surface passivation appears to be the main reason of the enhanced passivation quality.

\section{ACKNOWLEDGMENTS}

This project has been supported by the Australian Government through the Australian Solar Institute, part of the Clean Energy Initiative. The authors would like to acknowledge the support of the project commercial partners, Transform Solar.

${ }^{1}$ A. G. Aberle, Prog. Photovoltaics 8, 473 (2000).

${ }^{2}$ J. H. Zhao, A. H. Wang, and M. A. Green, Prog. Photovoltaics 7, 471 (1999).

${ }^{3}$ M. A. Green, Prog. Photovoltaics 17, 183 (2009).

${ }^{4}$ Y. Tsunomura, Y. Yoshimine, M. Taguchi, T. Baba, T. Kinoshita, H. Kanno, H. Sakata, E. Maruyama, and M. Tanaka, Sol. Energy Mater. Sol. Cells 93, 670 (2009).

${ }^{5}$ R. Hezel and R. Schorner, J. Appl. Phys. 52, 3076 (1981).

${ }^{6}$ W. Soppe, H. Rieffe, and A. Weeber, Prog. Photovoltaics 13, 551 (2005).

${ }^{7}$ A. G. Aberle, Crystalline Silicon Solar Cells: Advanced Surface Passivation and Analysis (University of New South Wales, Sydney, 1999).

${ }^{8}$ S. Dauwe, L. Mittelstadt, A. Metz, and R. Hezel, Prog. Photovoltaics 10, 271 (2002).

${ }^{9}$ G. Agostinelli, A. Delabie, P. Vitanov, Z. Alexieva, H. F. W. Dekkers, S. De Wolf, and G. Beaucarne, Sol. Energy Mater. Sol. Cells 90, 3438 (2006).

${ }^{10}$ B. Hoex, S. B. S. Heil, E. Langereis, M. C. M. van de Sanden, and W. M. M. Kessels, Appl. Phys. Lett. 89, 042112 (2006).

${ }^{11}$ J. Schmidt, A. Merkle, R. Brendel, B. Hoex, M. C. M. van de Sanden, and W. M. M. Kessels, Prog. Photovoltaics 16, 461 (2008).

${ }^{12}$ B. Hoex, J. Schmidt, R. Bock, P. P. Altermatt, M. C. M. van de Sanden, and W. M. M. Kessels, Appl. Phys. Lett. 91, 112107 (2007).

${ }^{13}$ J. Benick, B. Hoex, M. C. M. van de Sanden, W. M. M. Kessels, O. Schultz, and S. W. Glunz, Appl. Phys. Lett. 92, 253504 (2008).

${ }^{14}$ G. Dingemans, N. M. Terlinden, D. Pierreux, H. B. Profijt, M. C. M. van de Sanden, and W. M. M. Kessels, Electrochem. Solid-State Lett. 14, H1 (2011).

${ }^{15}$ W. Dawei, J. Rui, D. Wuchang, C. Chen, W. Deqi, C. Wei, L. Haofeng, Y. Huihui, and L. Xinyu, J. Semicond. 32, 094008 (2011).

${ }^{16}$ A. Richter, J. Benick, M. Hermle, and S. W. Glunz, Phys. Status Solidi (RRL) 5, 202 (2011).

${ }^{17}$ H. Nagel, A. G. Aberle, and R. Hezel, Prog. Photovoltaics 7, 245 (1999).

${ }^{18}$ S. Zaitsu, T. Jitsuno, M. Nakatsuka, T. Yamanaka, and S. Motokoshi, Appl. Phys. Lett. 80, 2442 (2002).

${ }^{19}$ P. Repo, H. Talvitie, S. Li, J. Skarp, and H. Savin, Energy Procedia 8, 681 (2011).

${ }^{20}$ B. G. Lee, J. Skarp, V. Malinen, S. Li, S. Choi, and H. M. Branz, in 38th IEEE Photovoltaic Specialists Conference, Austin (2012), p. 1066.

${ }^{21}$ Y. Takahashi, A. Ogiso, R. Tomoda, K. Sugiyama, H. Minoura, and M. Tsuiki, J. Chem. Soc., Faraday Trans. 1 78, 2563 (1982).

${ }^{22}$ D. E. Kane and R. M. Swanson, in 18th IEEE Photovoltaic Specialists Conference, Las Vegas (1981), p. 578.

${ }^{23}$ K. R. McIntosh, S. C. Baker-Finch, N. E. Grant, A. F. Thomson, S. Singh, and I. D. Baikie, J. Electrochem. Soc. 156, G190 (2009).

${ }^{24}$ G. Dingemans, R. Seguin, P. Engelhart, M. C. M. van de Sanden, and W. M. M. Kessels, Phys. Status Solidi (RRL) 4, 10 (2010).

${ }^{25}$ B. Hoex, J. J. H. Gielis, M. C. M. van de Sanden, and W. M. M. Kessels, J. Appl. Phys. 104, 113703 (2008).

${ }^{26}$ N. M. Terlinden, G. Dingemans, M. C. M. V. de Sanden, and W. M. M. Kesselsa, Appl. Phys. Lett. 96, 112101 (2010).

${ }^{27}$ J. Aarik, A. Aidla, T. Uustare, and V. Sammelselg, J. Cryst. Growth 148, 268 (1995).

${ }^{28}$ J. Aarik, A. Aidla, A. A. Kiisler, T. Uustare, and V. Sammelselg, Thin Solid Films 305, 270 (1997).

${ }^{29}$ R. S. Muller and T. I. Kamins, Device Electronics for Integrated Circuits, 2nd ed. (Wiley, New York, 1986).

${ }^{30}$ D. K. Schroder, Semiconductor Material and Device Characterization, 2nd ed. (John Wiley \& Sons, New York, 1998).

${ }^{31}$ L. M. Terman, Solid-State Electron. 5, 285 (1962).

${ }^{32}$ E. H. Nicollian and J. R. Brews, MOS Physics and Technology (Wiley, New York, 1982).

${ }^{33}$ S. Chakraborty, M. K. Bera, P. K. Bose, and C. K. Maiti, Semicond. Sci. Technol. 21, 335 (2006). 
${ }^{34}$ K. J. Weber, H. Jin, and C. Zhang, in 24th European Photovoltaic Solar Energy Conference, Hamburg (2009), p. 534.

${ }^{35}$ B. Veith, F. Werner, D. Zielke, R. Brendel, and J. Schmidt, Energy Procedia 8, 307 (2011).

${ }^{36}$ R. Matero, A. Rahtu, and M. Ritala, Chem. Mater. 13, 4506 (2001).
${ }^{37}$ J. D. Ferguson, A. R. Yoder, A. W. Weimer, and S. M. George, Appl. Surf. Sci. 226, 393 (2004).

${ }^{38}$ G. Dingemans and W. M. M. Kessels, ECS Trans. 41, 293 (2011)

${ }^{39}$ G. Dingemans, F. Einsele, W. Beyer, M. C. M. van de Sanden, and W. M. M. Kessels, J. Appl. Phys. 111, 093713 (2012). 